\title{
Editorial
}

\section{Sobre autoplágio: ou quantos artigos vale uma tese}

\section{Editorial}

\author{
About Autoplagiarism: Or How Many Papers is a Thesis Worth
}

\section{SiLvia LIEBEL*}

Contrariamente à máxima popular que diz que o plágio é uma forma de elogio, a academia estabeleceu regras claras (ainda que algumas vezes, não aplicadas) a respeito de trabalhos cujos "tributos" à pesquisa alheia deixam escapar o principal: a referenciação ao autor ou autora a quem se deve o texto. Mas se o plágio fosse uma forma de elogio, o que se diria a respeito do autoplágio? Autoconfiança, narcisismo, preguiça ou de fato pouco se diria, afinal, tudo o que produzo me pertence, para usar como bem me aprouver?

O conjunto de uma produção sólida raramente é linear. Ainda que seu começo e desdobramentos possam ser datados, ideias, conceitos e metodologias são revistos, novas fontes encontradas, posições retrabalhadas, inspirações tomadas em diferentes paragens. Quando as expectativas se mantêm, contudo, e isso é traduzido em manuscritos que repetem ipsis litteris "apenas questões teóricas", "apenas metodologia” ou "apenas elementos secundários" em meio a um ponto original, os editores se veem confrontados pelos dilemas em torno do quanto é possível ou desejável copiar-se a si mesmo. Embora esse certamente seja um caminho

\footnotetext{
* https://orcid.org/0000-0002-7435-6902

Editora Chefe de Varia Historia

Universidade Federal de Minas Gerais, Departamento de História Av. Antônio Carlos 6627, Belo Horizonte, MG, 31.270-901, Brasil liebel.seiziemiste@gmail.com
} 
seguro, pois remete ao que se mostrou bem-sucedido, nada promove de inovação, antes deixa a impressão de, pardon my French, encher linguiça, esvaziando, portanto, a importância originalmente atribuída aos trechos copiados. Limitando-nos a discutir a questão ainda nebulosa do autoplágio, na medida em que o plágio, enquadrado como crime, está sujeito a medidas judiciárias - o que não impede, ocasionalmente, aquele ou aquela que o comete de ascender aos principais cargos nas políticas públicas referentes ao ensino e à pesquisa no Brasil recente -, propomos uma discussão centrada na ética acadêmica. Não nos voltamos, assim, a definir uma porcentagem arbitrária de autoplágio que seria aceita em um manuscrito, mas a refletir sobre sua natureza e efeitos na difusão científica.

As diferentes formas de autoplágio citadas por Spinak (2013) como uma "zona cinzenta" incluem a reutilização de dados; a menor parte publicável, ou seja, a fragmentação de um trabalho em várias partes que remetem, todas, a um mesmo argumento central, também conhecida como salami slicing; a inconsciência do autor sobre a prática, quando não há uma política editorial clara; a fragmentação de uma tese doutoral. Essas formas, naturalmente, variam, na medida em que um conjunto de dados pode fornecer as mesmas respostas para uma dada disciplina e sustentar diferentes perspectivas e abordagens para outra.

A política editorial de Varia Historia deixa poucas dúvidas aos autores e autoras, explicitando em suas instruções:

Varia Historia só publica manuscritos originais. Nossa expectativa é receber textos que não tenham semelhança substancial com outros já publicados pelo/a proponente, seja em formato impresso, seja em formato eletrônico. É importante, também, que o artigo não seja submetido a nenhum outro processo editorial. No caso de dissertações e teses não publicadas, espera-se um trabalho de reescritura para que o texto não seja considerado como autoplágio. ${ }^{1}$

1 As regras estão disponíveis tanto no site da revista (http://www.variahistoria.org/instrues), quanto no Scielo (https://www.scielo.br/revistas/vh/pinstruc.htm). 
E, em nosso código ético, constam como responsabilidade dos autores:

Garantir que o artigo (ou parte significante) não foi publicado em nenhum outro lugar, e não está submetido ou foi aceito em nenhuma outra publicação. (...) Enviar artigos originais, sem plágios ou autoplágios, sem dados fraudulentos, e que não sejam o que se chama de "Menor Parte Publicável".

A submissão de um artigo implica, ainda que de forma tácita, a concordância com os termos do periódico, que não estão escondidos em um contrato inacessível ou de letras miúdas. Não apenas explicitamos que apenas artigos inéditos são publicados - e a reutilização de textos anteriores sem a devida indicação de fonte é, assim, um empecilho à publicação e coloca problemas severos para a avaliação cega pelos pares -, como deixamos claro que isso se aplica a materiais em formato impresso ou eletrônico (o que inclui trabalhos em anais de eventos), e que dissertações e teses devem ser reescritas. Reescritura não significa redundância, e difundir uma pesquisa desse porte implica em cuidados por parte dos proponentes em não mutilar seus próprios textos. Mas o nível de explicitação da revista deveria realmente ser necessário? Como já salientado por pesquisadores da linguagem, o autoplágio é uma prática que passa longe da "ingenuidade", visto tratar-se de um ato deliberado de um autor que conhece as regras do campo acadêmico e da divulgação científica (FURLANETTO; RAUEN; SIEBERT, 2018, p. 11).

Não se trata de abolir o recurso a trabalhos anteriores, mas, precisamente, de citá-los no texto, o que é encarado como qualquer outra citação - em uma quantidade que demonstre bom senso, naturalmente. Sendo os limites para a chamada menor parte publicável ainda objeto de debate, optamos por abolir a prática de nosso processo editorial. Há uma grande diferença entre os resultados preliminares de uma pesquisa que podem ajudar na construção de uma tese e que são publicados no

2 Disponível em: < http://www.variahistoria.org/cdigo-tico >. 
formato de artigo científico, e o processo inverso, de fragmentar uma tese que consiste em um trabalho coeso - e, espera-se, original -, idealmente a ser transformado em livro, e fragmentá-lo. Quantos artigos, afinal, vale uma tese de doutorado? De que formas deve ser medida a produção de recém-doutores?

Trata-se de um problema, contudo, que não é restrito às páginas de dissertações e teses disponibilizadas online que recheiam artigos apresentados como inéditos. Varia Historia, a despeito do anúncio das regras do jogo de divulgação científica, rejeita com frequência preocupante manuscritos com trechos substanciais já publicados em outros artigos ou capítulo de livros, de pesquisadores nacionais e estrangeiros, que não são referenciados. Sintomas não apenas do publish or perish, mas de uma aparente despreocupação com as boas práticas acadêmicas, esses elementos integram o vasto panorama de questionamentos sobre as formas aceitáveis de divulgação científica em um cenário que exige um produtivismo crescente. Nele, os números se traduzem em financiamento que, por sua vez, implicam em novas publicações, sem de fato causar admiração a ninguém esse círculo vicioso no qual poucos conseguem manter criatividade, originalidade, qualidade e alta produção em sintonia.

Uma discussão mais ampla sobre ética na produção acadêmica e os problemas da ênfase dos números sobre a qualidade ainda está em estágio embrionário. Esse processo poderia ser beneficiado com uma reflexão desde o início dos cursos de graduação, explicitando-se que as normas técnicas vão além de um ideal de formatação, mas implicam também no respeito ao texto do outro, na identificação da escrita pessoal e da pesquisa desenvolvida pelos predecessores, na separação entre a própria voz e aquilo que o professor fala e é apropriado, como se fosse senso comum e não resultado de leituras particulares. Enquanto isso, o árduo trabalho de desembaraçar o novelo de um artigo que mescla produção original, autocitação e autoplágio resta, enfim, ao encargo do editor. 


\section{$\propto$}

O número 74 de Varia Historia é composto pelo dossiê "Processos judiciais e escrita da história na América Latina”, por artigos livres e resenhas. Em sua apresentação do dossiê, os organizadores Mariana Armond Dias Paes e Pedro Cantisano pontuam a renovação no uso dos processos judiciais pela historiografia recente. Abrindo a seção de artigos livres, William de Souza Martins apresenta os embates em torno da entrada de nativos brasileiros e afrodescendentes na Ordem Terceira de São Francisco do Pará em meados do século XVIII. Eliane Cristina Fleck e Mauro Dillmann perpassam como a gula era concebida na tratadística médica e religiosa que circulou em Portugal também nos Setecentos. Já no século XX, Clarice Gontarski Speranza analisa a presença da mão-de-obra estrangeira nas minas de carvão do Rio Grande do Sul, e Ana Carina Azevedo retraça a reforma administrativa promovida pelo Estado Novo português. Nossa seção de resenhas fecha o número com as apresentações de Sergio Urzúa-Martínez sobre obra editada por Juan Pablo Bohoslavsky, Karinna Fernández e Sebastián Smart acerca dos atores econômicos que apoiaram a ditadura chilena e sua violação de direitos; e Juliana Souza apresenta obra ainda inédita em português de Donald Worster, um marco na história ambiental estadunidense. Varia Historia é uma revista de acesso aberto e gratuito, para seus autores e leitores.

\section{REFERÊNCIAS BIBLIOGRÁFICAS}

FURLANETTO, Maria Marta; RAUEN, Fábio José; SIEBERT, Silvânia. Plágio e autoplágio: desencontros autorais. Linguagem em (Dis)curso, v. 18, n. 1, p. 11-19, 2018.

SPINAK, Ernesto. Ética editorial e o problema do autoplágio. SciELO em Perspectiva, 2013. Disponível em: < http://www.revistahcsm.coc.fiocruz.br/ etica-editorial-e-o-problema-do-autoplagio >. Acesso em: 05 maio 2021. 